\title{
Infrastructure, Human Capital Development and Economic Growth in Transitional Countries
}

\author{
Kunofiwa Tsaurai \\ Ph.D., Associate Professor at the University of South Africa \\ Department of Finance, Risk Management and Banking, Pretoria, South Africa \\ e-mail: tsaurk@unisa.ac.za, kunofiwa.tsaurai@gmail.com
}

\author{
Adam Ndou \\ Lecturer at the University of South Africa, Department of Finance, \\ Risk Management and Banking, Pretoria, South Africa \\ e-mail: endouaa@unisa.ac.za
}

\begin{abstract}
This study investigated the impact of infrastructure and human capital development on economic growth in transitional economies. It also explored whether the interaction between infrastructural and human capital development enhanced economic growth in the transitional economies. Although the literature is awash with studies which investigated the separate impact of infrastructure and human capital development on economic growth, no study that the author is aware of has so far explored whether the interaction between infrastructure and human capital development enhances economic growth. The study mainly used a dynamic panel generalised methods of moments (GMM) approach by Arellano and Bond (1995), a framework that takes into account the dynamic nature of economic growth data and addresses the endogeneity issues normally associated with economic growth regression functions. Panel data analysis approaches such as pooled ordinary least squares (OLS), and fixed and random effects were used for comparison purposes and robustness tests. According to the dynamic GMM framework, the interaction between infrastructure and human capital development improved economic growth in transitional economies, in line with theoretical and empirical predictions. Random effects and pooled OLS show that the interaction between infrastructural and human capital development had a deleterious effect on economic growth, whilst according to the fixed effects approach, the interaction between these two variables had an insignificant positive influence on economic growth in transitional economies. Considering that the results from a dy-
\end{abstract}


namic panel GMM are considered to be more accurate due to the approach's ability to address the endogeneity problem and the dynamic nature of economic growth data, the current study recommends that transitional economies should implement policies that improve human capital development in order to enhance infrastructural development's ability to influence economic growth. Future studies should investigate not just one (human capital development), but all the conditional factors which must be in place before economic growth advantages triggered by infrastructure development are realised.

Keywords: human capital; infrastructure transitional economies; dynamic GMM

JEL: F43; J24; O18; P20

\section{Introduction}

Background of the study: The infrastructure-growth nexus has in the last two decades been a very popular topic among academics, politicians, researchers and economists in developing and emerging markets. This is because, through the aggregate production function, infrastructure development positively affects output, employment, productivity and welfare in the long run, which is consistent with Straub (2007). However, prior empirical studies on the infrastructure development-growth nexus produced mixed, divergent and conflicting findings which can be divided into three categories, namely the infrastructural development-led growth hypothesis, feedback effect and neutrality hypothesis. Despite a lack of consensus on the relationship between infrastructure and economic growth, the majority of the empirical work supports the infrastructure-led growth hypothesis. Moreover, empirical work on the infrastructural development-growth nexus in transitional economies is quite scant despite the fact that they have been the major recipients of foreign direct investment (flows alongside infrastructure development) in the last two decades, following Cavusgil et al. (2013). What is also notable is that the available empirical work on the infrastructure development-growth nexus wrongly assumed that the two variables are linearly related. In other words, to the author's best knowledge, none of the available empirical studies on the subject matter explored the conditions which must be available in a country before economic growth triggered by infrastructure development occurs. It is against this backdrop that this paper seeks to explore the combined effect of infrastructure and human capital development in enhancing economic growth in transitional economies.

Problem statement and research gap: Previous empirical studies investigated the separate impact of infrastructure and human capital development on economic growth. The majority of those empirical studies found that infrastructure and human capital development separately have a significant positive effect on economic growth. It should then follow that in a scenario where a country or countries have developed infrastructure and human capital development, economic growth is enhanced. As far 
as the author is aware, there is no existing study that has explored the combined effect of infrastructure and human capital development on economic growth. Besides, the majority of the empirical work on infrastructure-growth and/or the human capital development-growth nexus ignored the dynamic nature of growth data and the endogeneity issues that normally characterises the relationship between these variables.

Contribution of the study: The current study addresses the endogeneity problem and the dynamic nature of the economic growth variable by using the dynamic panel GMM estimation technique. To the best of the author's knowledge, this is the first study to investigate the impact of the interaction between infrastructure and human capital development on economic growth in transitional economies. The findings from such a study may guide the authorities in transitional economies in terms of drafting proper infrastructure and human capital development policies that enhance economic growth.

Organisation of the paper: Section 2 describes the theoretical literature on the relationship between infrastructure development and economic growth. Section 3 discusses the empirical work done so far on the infrastructure-growth nexus. Section 4 is the research methodological framework which describes the data, variables, proxies used, pre-estimation diagnostics, panel unit root tests, panel co-integration tests, data analysis and reports findings. Section 5 concludes. Section 6 is the reference list.

\section{Impact of infrastructure development on economic growth - Theoretical literature}

Next are some theoretical rationales which explain the impact of infrastructure on economic growth. Under the exogenous growth model, as supported by Mahembe and Odhiambo (2014), foreign technological infrastructure which flows alongside FDI is an input into the production function which enhances economic growth. Frone and Frone (2014) challenged the theory of including human capital in the production function to estimate economic growth, arguing that it is a public good funded by government saving and not necessarily exported to foreign markets; thus, the growth of public infrastructure may be inadequate in stimulating economic growth. Instead, they supported the view that infrastructure delivers basic services, such as electricity, water, transport, telecommunications and sanitation, which not only boost economic activities but indirectly reduce poverty and inequality.

The neoclassical growth model which was supported by Sahoo et al. (2012) argued that more investment in public and social infrastructure enhances education levels, health systems and human resources in the country, thereby increasing productivity and economic growth. Prud'homme (2004) noted that infrastructure development connects individuals to work, resources to factories and products to markets, thereby reducing the cost of doing business and expand market opportunities, thereby enhancing the competitiveness of a firm. Banerjee et al. (2012) observed that investment in transportation infrastructure reduces trade costs and enhances market mix which leads to convergence 
in prices, price stability and the efficient allocation of resources. This was confirmed by Zheng and Kuroda (2013), whose study noted that an improvement in transport infrastructure not only cuts trade expenses and boosts economic activities but also reduces income inequality by increasing industrial accumulation between China’s cities.

\section{The impact of infrastructure development on economic growth - Empirical literature}

The majority of related empirical studies noted that infrastructure development enhances economic growth. For example, a study by Frone and Frone (2014) used simple cross-country regression equations to estimate the correlation between water supply and sanitation infrastructure development and economic growth in Romania. The study found a strong positive correlation between the country's population connected to the water supply and sanitation networks to regional economic growth.

In investigating the influence of infrastructure development on enhancing economic growth in China, Sahoo et al. (2012) used time series data from 1975 to 2007. The study showed that infrastructure development influenced economic growth directly more than both private and public investment. Wu et al. (2013) study explored the incentives and outcomes of China's environmental policy using time series data (2000-2009). They found that investing in transportation infrastructure has a positive association with an increase in GDP and overall government revenues.

A study by Redding and Turner (2014) evaluated the relationship between the distribution of economic activity and transportation investment spending in China by developing a multi-region model to predict the association. Their study revealed that construction and improvements in transportation infrastructure influence the advancement of economic development. In a more recent study which was done in Belgium by Meersman and Nazemzadeh (2017), annual data was analysed through an aggregate modelling and causality test. The study showed that Belgium's GDP capita was positively linked to investment in roads, the rail network and port infrastructure. Jiang et al. (2017) used a panel dataset from 1986 to 2011 to investigate the bi-directional relationship between multimodal transportation infrastructure investment and economic growth in China. The study showed that transportation infrastructure investment had a positive effect on economic growth.

Table 1 shows a summary of empirical research on infrastructure development and economic growth. 
Table 1. Summary of empirical work on infrastructure development and economic growth

\begin{tabular}{|c|c|c|c|}
\hline Author & $\begin{array}{l}\text { Focal unit } \\
\text { of analysis }\end{array}$ & Methodology & Research findings \\
\hline $\begin{array}{l}\text { Sahoo and } \\
\text { Dash (2012) }\end{array}$ & $\begin{array}{l}\text { India, Paki- } \\
\text { stan, Bangla- } \\
\text { desh and Sri } \\
\text { Lanka }\end{array}$ & $\begin{array}{l}\text { Panel co-inte- } \\
\text { gration analysis }\end{array}$ & $\begin{array}{l}\text { The study showed that infrastructural } \\
\text { development enhanced output in South Asia. }\end{array}$ \\
\hline $\begin{array}{l}\text { Kumari and } \\
\text { Sharma } \\
(2017)\end{array}$ & India & \begin{tabular}{l|} 
Unrestricted \\
vector autore- \\
gressive regres- \\
sion analysis \\
\end{tabular} & $\begin{array}{l}\text { Economic and social infrastructure was found } \\
\text { to have had a positive influence on economic } \\
\text { growth in }\end{array}$ \\
\hline $\begin{array}{l}\text { Pradhan and } \\
\text { Bagchi (2012) }\end{array}$ & India & $\begin{array}{l}\text { Vector Error } \\
\text { Correction } \\
\text { Model (VECM) }\end{array}$ & $\begin{array}{l}\text { The study observed a bidirectional causality } \\
\text { between transport infrastructure and economic } \\
\text { growth in India. The study also found that } \\
\text { expanding transport infrastructure, together } \\
\text { with gross capital formation, strongly enhanced } \\
\text { growth in India. }\end{array}$ \\
\hline $\begin{array}{l}\text { Buys et al. } \\
(2010)\end{array}$ & $\begin{array}{l}\text { Sub-Saharan } \\
\text { Africa }\end{array}$ & $\begin{array}{l}\text { Spatial network } \\
\text { analysis and } \\
\text { gravity trade } \\
\text { model }\end{array}$ & $\begin{array}{l}\text { The study noted that upgrading road networks } \\
\text { was necessary to facilitate economic growth } \\
\text { activities such as trade. }\end{array}$ \\
\hline $\begin{array}{l}\text { Daido and } \\
\text { Tabata (2013) }\end{array}$ & $\begin{array}{l}\text { East Asian } \\
\text { countries }\end{array}$ & $\begin{array}{l}\text { Panel data } \\
\text { analysis }\end{array}$ & $\begin{array}{l}\text { The study showed that public infrastructural in- } \\
\text { vestment decisions encouraged economic growth } \\
\text { in East Asian countries. }\end{array}$ \\
\hline $\begin{array}{l}\text { Calderon and } \\
\text { Serven (2010) }\end{array}$ & $\begin{array}{l}\text { African } \\
\text { countries }\end{array}$ & $\begin{array}{l}\text { Cross-sectional } \\
\text { data analysis }\end{array}$ & $\begin{array}{l}\text { The study found that infrastructural development } \\
\text { immensely contributed to growth, equity and } \\
\text { poverty reduction in Africa. }\end{array}$ \\
\hline $\begin{array}{l}\text { Kodongo and } \\
\text { Ojah (2016) }\end{array}$ & $\begin{array}{l}45 \text { Sub-Saha- } \\
\text { ran African } \\
\text { countries }\end{array}$ & $\begin{array}{l}\text { Generalised } \\
\text { Method } \\
\text { of Moments } \\
\text { (GMM) system }\end{array}$ & $\begin{array}{l}\text { They observed that increased spending in in- } \\
\text { frastructural development enhanced economic } \\
\text { growth in Sub-Saharan African countries. }\end{array}$ \\
\hline $\begin{array}{l}\text { Pradhan et al. } \\
\text { (2014) }\end{array}$ & $\begin{array}{l}\text { G-20 } \\
\text { countries }\end{array}$ & VECM & $\begin{array}{l}\text { The development of telecommunication infra- } \\
\text { structure was found to have had a significant } \\
\text { positive impact on the growth of the economy } \\
\text { in G-20 countries. }\end{array}$ \\
\hline $\begin{array}{l}\text { Matalqah and } \\
\text { Warad (2017) }\end{array}$ & $\begin{array}{l}12 \text { Arab } \\
\text { countries }\end{array}$ & $\begin{array}{l}\text { Cross-sectional } \\
\text { data analysis }\end{array}$ & $\begin{array}{l}\text { They found that investing in telecommunication } \\
\text { infrastructure had a positive and substantial } \\
\text { impact on economic growth in the long-term } \\
\text { in the } 12 \text { Arab countries. }\end{array}$ \\
\hline Batuo (2015) & $\begin{array}{l}44 \text { African } \\
\text { countries }\end{array}$ & $\begin{array}{l}\text { Panel data } \\
\text { analysis }\end{array}$ & $\begin{array}{l}\text { Telecommunication infrastructural develop- } \\
\text { ment-led growth was detected in the African } \\
\text { countries. }\end{array}$ \\
\hline $\begin{array}{l}\text { Sahin et al. } \\
(2014)\end{array}$ & $\begin{array}{l}\text { European } \\
\text { Union } \\
\text { countries } \\
\end{array}$ & $\begin{array}{l}\text { GMM } \\
\text { Approach }\end{array}$ & $\begin{array}{l}\text { The study showed that railway, road and energy } \\
\text { infrastructure had a positive influence on eco- } \\
\text { nomic growth in the European countries. }\end{array}$ \\
\hline $\begin{array}{l}\text { Shabani and } \\
\text { Safaie (2018) }\end{array}$ & Iran & $\begin{array}{l}\text { Time series } \\
\text { data analysis }\end{array}$ & $\begin{array}{l}\text { The study found that main road and railway } \\
\text { infrastructure had a positive impact on economic } \\
\text { growth in the provinces of Iran. }\end{array}$ \\
\hline
\end{tabular}




\begin{tabular}{|c|c|c|c|}
\hline Author & $\begin{array}{l}\text { Focal unit } \\
\text { of analysis }\end{array}$ & Methodology & Research findings \\
\hline $\begin{array}{l}\text { Zheng and } \\
\text { Kuroda (2013) }\end{array}$ & $\begin{array}{l}\text { Cities } \\
\text { in China }\end{array}$ & $\begin{array}{l}\text { Panel data } \\
\text { analysis }\end{array}$ & $\begin{array}{l}\text { The study showed that developments in trans- } \\
\text { port and knowledge infrastructure led to a de- } \\
\text { crease in trade costs of goods and services and } \\
\text { consequently enhanced economic growth. }\end{array}$ \\
\hline Cantu (2017) & 94 countries & GMM approach & $\begin{array}{l}\text { Economic growth was positively influenced } \\
\text { by transport and communication infrastructure. }\end{array}$ \\
\hline $\begin{array}{l}\text { Donou-Adon- } \\
\text { sou and Lim } \\
(2016)\end{array}$ & $\begin{array}{l}\text { Sub-Saha- } \\
\text { ran African } \\
\text { countries }\end{array}$ & $\begin{array}{l}\text { Variable-Gen- } \\
\text { eralised Meth- } \\
\text { od of Moments }\end{array}$ & $\begin{array}{l}\text { Internet and cellphones infrastructure was } \\
\text { found to have had a significant positive influence } \\
\text { on economic growth. }\end{array}$ \\
\hline $\begin{array}{l}\text { Shi et al. } \\
\text { (2017) }\end{array}$ & China & VECM & $\begin{array}{l}\text { The study revealed that road network infrastruc- } \\
\text { ture had a negative impact on economic growth } \\
\text { in China. }\end{array}$ \\
\hline $\begin{array}{l}\text { Rodri- } \\
\text { guez-Pose } \\
\text { et al. (2012) }\end{array}$ & Greece & $\begin{array}{l}\text { Time series } \\
\text { regression } \\
\text { analysis }\end{array}$ & $\begin{array}{l}\text { Infrastructural development led to an insignifi- } \\
\text { cant impact on economic growth in Greece. }\end{array}$ \\
\hline $\begin{array}{l}\text { Banerjee } \\
\text { et al. (2012) }\end{array}$ & China & $\begin{array}{l}\text { Time series } \\
\text { regression } \\
\text { analysis }\end{array}$ & $\begin{array}{l}\text { Infrastructural development was found to be } \\
\text { moderately related to economic growth in China. }\end{array}$ \\
\hline $\begin{array}{l}\text { Crescenzi } \\
\text { and Rodri- } \\
\text { guez-Pose } \\
(2012)\end{array}$ & $\begin{array}{l}\text { European } \\
\text { Union }\end{array}$ & $\begin{array}{l}\text { Two-way fixed } \\
\text { effect static } \\
\text { and GMM }\end{array}$ & $\begin{array}{l}\text { Infrastructural endowment was found to be } \\
\text { a moderately poor predictor of economic growth } \\
\text { in the European Union. }\end{array}$ \\
\hline $\begin{array}{l}\text { Farhadi } \\
(2015)\end{array}$ & $\begin{array}{l}18 \text { OECD } \\
\text { countries }\end{array}$ & GMM & $\begin{array}{l}\text { The impact of infrastructural development } \\
\text { on economic growth in the OECD countries was } \\
\text { found to be insignificant. }\end{array}$ \\
\hline
\end{tabular}

\section{Methodological framework of the research}

This section describes the econometric model framework, variables and related theory intuition, data, pre-estimation diagnostics and research findings.

Econometric Model Framework: The current study tested the following three equations.

$$
\begin{gathered}
\text { GROWTH }_{i, t}=\beta_{0}+\beta_{1} \text { INFR }_{i, t}+\beta_{2} \text { HCD }_{i, t}+X_{i, t}+\mu_{i}+\varepsilon_{i t} \\
\text { GROWTH }_{i, t}=\beta_{0}+\beta_{1} \text { GROWTH }_{i t-1}+\beta_{2} \text { INFR }_{i, t}+\beta_{3} H C D_{i, t}+ \\
\beta_{4}\left(\text { INFR }_{i, t} . H C D_{i, t}\right)+\beta_{5} X_{i, t}+\mu_{i}+\varepsilon_{i t}
\end{gathered}
$$




$$
\begin{gathered}
\mathrm{GROWTH}_{i, t}=\beta_{0}+\beta_{1} \text { INFR }_{i, t}+\beta_{2} \mathrm{HCD}_{i, t}+\beta_{3}\left(\mathrm{INFR}_{i, t} . H C D_{i, t}\right)+ \\
\beta_{4} X_{i, t}+\mu_{i}+\varepsilon_{i t}
\end{gathered}
$$

Where GROWTH, INFR, HCD and X respectively represent economic growth, infrastructural development, human capital development and other explanatory variables. For the purposes of the current study, the explanatory variables used include exchange rates, trade openness, financial development, population growth, inflation, savings and FDI (foreign direct investment). $\beta_{0}$ to $\beta_{5}$ stand for the coefficients of the respective variables. Specifically, $\beta_{4}$ is the coefficient of the interaction term $\left(I N F R_{i, t}\right.$. $\left.H C D_{i, t}\right)$, consistent with Chang et al. (2009, p. 8). $t$ and $i$ are subscripts respectively standing for time and country. $\mu_{i}$ is the unobserved time-invariant and country-specific effect whilst the error term is represented by $\varepsilon_{i t}$. A significant positive sign of $\beta_{4}$ indicates that the interaction between infrastructure and human capital development enhances economic growth in transitional economies. Equation 2 was estimated using the dynamic panel GMM methodology whilst other panel data analysis frameworks (fixed effects, random effects and pooled OLS) were employed in the estimation of equation 3. The major benefit of using these panel data analysis methods is that they are capable of quantifying the influence of one variable on another in cases where cross-sectional and time series data analysis cannot be done, which is consistent with Wooldridge (2002).

\section{Variables, theory intuition and the direction of the causality relationship}

Table 2. Explanatory variables for economic growth

\begin{tabular}{|l|l|l|c|}
\hline \multicolumn{1}{|c|}{ Variable } & Proxy used \\
$\begin{array}{l}\text { Human capital } \\
\text { (HCDelopment }\end{array}$ & $\begin{array}{l}\text { Human cap- } \\
\text { ital develop- } \\
\text { ment index }\end{array}$ & $\begin{array}{l}\text { According to Pradhan and Abraham (2002) } \\
\text { and Anochiwa and Maduka (2014), human } \\
\text { capital development positively influences } \\
\text { economic growth as an educated and highly } \\
\text { skilled workforce brings new ideas, techno- } \\
\text { logical innovations and technical expertise, } \\
\text { which consequently improves labour pro- } \\
\text { ductivity. On the other hand, spending more } \\
\text { on human capital development at the expense } \\
\text { of direct production promotion, economic } \\
\text { activities may retard economic growth in the } \\
\text { short run. }\end{array}$ & $+/-$ \\
\hline $\begin{array}{l}\text { Foreign direct } \\
\text { investment } \\
\text { (FDI) }\end{array}$ & $\begin{array}{l}\text { Net FDI } \\
\text { inflows } \\
\text { (\% of GDP) }\end{array}$ & $\begin{array}{l}\text { FDI does not only injects capital into the } \\
\text { economy, but it brings with it skills, expertise, } \\
\text { technological progress, knowledge and ideas, } \\
\text { all of which enhance productivity in the host } \\
\text { country (Gui-Diby 2014). }\end{array}$ & \\
\hline
\end{tabular}




\begin{tabular}{|c|c|c|c|}
\hline Variable & Proxy used & Theory intuition & Expected sign \\
\hline Savings & $\begin{array}{l}\text { GDP per cap- } \\
\text { ita }\end{array}$ & $\begin{array}{l}\text { According to Jagadeesh (2015), savings is an } \\
\text { important and integral part of economic } \\
\text { growth as it supports fixed capital } \\
\text { accumulation. Turan and Gjergji (2014) } \\
\text { state that savings have a long-run effect } \\
\text { on economic growth by boosting the general } \\
\text { level of investment in the economy. On the } \\
\text { other hand, savings do not have a significant } \\
\text { impact on the economy if they are not } \\
\text { directed towards investment activities. }\end{array}$ & $+/-$ \\
\hline $\begin{array}{l}\text { Inflation rate } \\
\text { (INFL) }\end{array}$ & $\begin{array}{l}\text { Inflation con- } \\
\text { sumer prices } \\
\text { (annual \%) }\end{array}$ & $\begin{array}{l}\text { High inflation negatively influences economic } \\
\text { growth by increasing the cost of borrowing, } \\
\text { lowering the rate of capital investment and } \\
\text { discouraging investments (Miftahu and Rosni } \\
\text { 2017). On the other hand, high inflation helps } \\
\text { to mobilise savings and investments in the } \\
\text { economy as economic agents seek inflation } \\
\text { hedging investment vehicles that cushion } \\
\text { them against inflation. }\end{array}$ & $+/-$ \\
\hline $\begin{array}{l}\text { Population } \\
\text { growth }\end{array}$ & $\begin{array}{l}\text { Population } \\
\text { growth } \\
\text { (annual \%) }\end{array}$ & $\begin{array}{l}\text { Higher levels of population create a bigger } \\
\text { market for goods and services thereby attract- } \\
\text { ing FDI and consequently enhancing econom- } \\
\text { ic growth, in line with Jorgenson's (1963) mar- } \\
\text { ket size hypothesis. }\end{array}$ & + \\
\hline $\begin{array}{l}\text { Financial devel- } \\
\text { opment (FIN) }\end{array}$ & $\begin{array}{l}\text { Outstand- } \\
\text { ing domestic } \\
\text { private debt } \\
\text { securities } \\
\text { (\% of GDP) }\end{array}$ & $\begin{array}{l}\text { According to Adu et al. (2013), financial } \\
\text { development positively influences economic } \\
\text { growth through its ability to mobilise savings } \\
\text { and spearhead investment activities in the } \\
\text { economy. However, Keynes (1936) noted } \\
\text { that financial sector volatility non-efficiently } \\
\text { distributes resources and retards economic } \\
\text { growth. }\end{array}$ & $+/-$ \\
\hline $\begin{array}{l}\text { Trade openness } \\
\text { (OPEN) }\end{array}$ & $\begin{array}{l}\text { Total exports } \\
\text { and imports } \\
\text { (\% of GDP) }\end{array}$ & $\begin{array}{l}\text { According to Huchet-Bourdon et al. (2018), } \\
\text { trade openness has a negative impact } \\
\text { on economic growth in countries that produce } \\
\text { low-quality products and depend on imports. } \\
\text { This view was supported by Zahonogo (2016), } \\
\text { who observed that trade openness negatively } \\
\text { influences economic growth in developing } \\
\text { countries whose import levels are not } \\
\text { effectively controlled. }\end{array}$ & - \\
\hline Exchange rate & $\begin{array}{l}\text { Total exports } \\
\text { and imports } \\
\text { (\% of GDP) }\end{array}$ & $\begin{array}{l}\text { Chirwa and Odhiambo (2016) observed that } \\
\text { a decrease in real exchange led to economic } \\
\text { growth through an increase in exports. } \\
\text { According to Korkmaz (2013), depreciating } \\
\text { the exchange rate promotes exports, } \\
\text { and increases FDI and FPI inflows. The } \\
\text { literature also argues that a strong currency } \\
\text { makes domestic products less competitive } \\
\text { in international markets, reduces exports } \\
\text { and FDI inflows, and ultimately slows down } \\
\text { economic growth. }\end{array}$ & $+/-$ \\
\hline
\end{tabular}




\begin{tabular}{|l|l|l|c|}
\hline \multicolumn{1}{|c|}{ Variable } & \multicolumn{1}{|c|}{ Proxy used } & \multicolumn{1}{c|}{ Theory intuition } & Expected sign \\
\hline $\begin{array}{l}\text { Interaction } \\
\text { between } \\
\text { infrastructural } \\
\text { and human } \\
\text { capital } \\
\text { development }\end{array}$ & $\begin{array}{l}\text { Electric pow- } \\
\text { er consump- } \\
\text { tion (kWh per } \\
\text { capita) and } \\
\text { human capital } \\
\text { development } \\
\text { index respec- } \\
\text { tively }\end{array}$ & $\begin{array}{l}\text { Electricity and electricity infrastructure has } \\
\text { a positive impact on educational attainment } \\
\text { as it improves the learning environment which } \\
\text { encourages children to attend school through } \\
\text { connecting educational equipment, laborato- } \\
\text { ries and communications instruments to facil- } \\
\text { itate learning and economic growth and de- } \\
\text { velopment (Shafiq 2007). Ajakaiye and Ncube } \\
\text { (2010) argued that adequate infrastructure } \\
\text { positively influences human capital develop- } \\
\text { ment and improves the value of life by boost- } \\
\text { ing productivity and sustainable econom- } \\
\text { ic growth. The argument is that investment } \\
\text { in social infrastructure improves literacy, bet- } \\
\text { ter health and skills, which leads to more pro- } \\
\text { ductivity and economic growth (Pietak, 2014). }\end{array}$ & + \\
& & & \\
\hline
\end{tabular}

Source: Author's own compilation.

Data: This paper used panel data from 2000 to 2014 extracted from the United Nations Conference on Trade and Development, various United Nations Development Programme reports, International Financial Statistics, International Monetary Fund (IMF), World Development Indicators, International Financial Statistics, Global Financial Indicators databases. Transitional economies which were used include Argentina, Indonesia, Malaysia, Mexico, Hong Kong, Singapore, Thailand, India, the Philippines, South Korea, Brazil, China, Colombia, Peru and Turkey, in line with the IMF's (2015) report and data availability linked decisions.

Pre-estimation diagnostics: Table 3 shows correlation analysis whilst Table 4 contains the descriptive statistical results.

Table 3. Correlation analysis

\begin{tabular}{|l|c|c|c|c|c|c|c|c|c|c|}
\cline { 2 - 13 } \multicolumn{1}{c|}{} & GDP & INFR & HCD & FDI & INFL & SAV & OPEN & EXCH & POP & FIN \\
\hline GDP & 1.00 & & & & & & & & & \\
\hline INFR & $0.8^{* * *}$ & 1.00 & & & & & & & & \\
\hline HCD & $0.7^{* * *}$ & $0.8^{* * *}$ & 1.00 & & & & & & & \\
\hline FDI & $0.8^{* * *}$ & $0.5^{* * *}$ & $0.5^{* * *}$ & 1.00 & & & & & & \\
\hline INFL & $-0.2^{* * *}$ & $-0.2^{* * *}$ & $-0.17^{* *}$ & $-0.2^{* * *}$ & 1.00 & & & & & \\
\hline SAV & $0.4^{* * *}$ & $0.5^{* * *}$ & $0.3^{* * *}$ & $0.3^{* * *}$ & $-0.3^{* * *}$ & 1.00 & & & & \\
\hline OPEN & $0.8^{* * *}$ & $0.7^{* * *}$ & $0.6^{* * *}$ & $0.8^{* * *}$ & $-0.2^{* * *}$ & $0.5^{* * *}$ & 1.00 & & & \\
\hline EXCH & $-0.2^{* * *}$ & $-0.2^{* * *}$ & $-0.2^{* * *}$ & $-0.2^{* *}$ & 0.07 & 0.03 & $-0.2^{* *}$ & 1.00 & & \\
\hline POP & 0.08 & -0.1 & -0.1 & 0.01 & 0.07 & 0.06 & $0.2^{* * *}$ & 0.004 & 1.00 & \\
\hline FIN & $0.2^{* * *}$ & $0.6^{* * *}$ & $0.4^{* * *}$ & -0.03 & $-0.3^{* * *}$ & $0.5^{* * *}$ & $0.2^{* * *}$ & $-0.16^{* *}$ & $-0.3^{* * *}$ & 1.00 \\
\hline
\end{tabular}

Note: ${ }^{* * *} /{ }^{* *} / *$ denotes statistical significance at the 1\%/5\%/10\% level respectively.

Source: Author's own compilation from E-Views. 


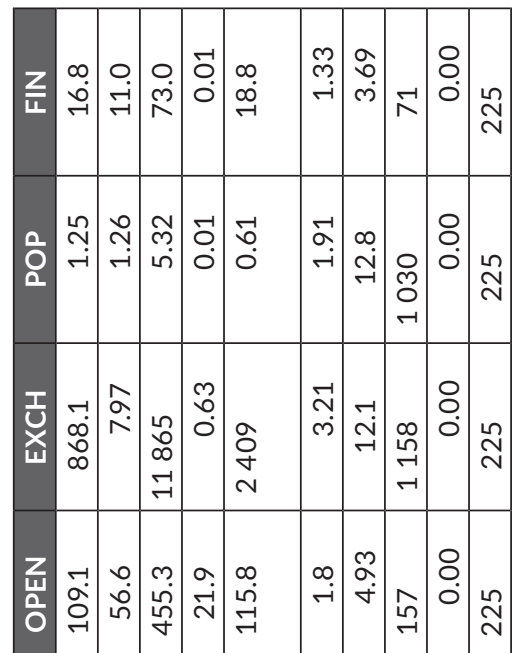

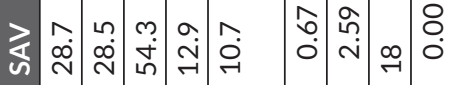

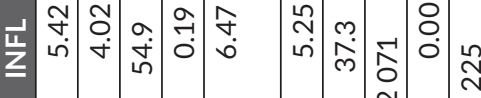

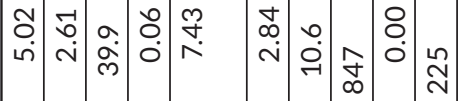

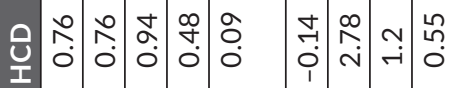

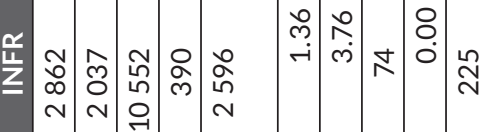




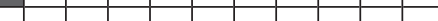


From Table 3, the problem of multicollinearity was found to be absent between the majority of variables (maximum correlation is 0.8 ) except for a correlation between FDI and trade openness, which is $86 \%$. The finding resonates with Stead's (1996) observation. The correlation between GDP and its explanatory variables (see Table 3 ) is in sync with the theoretical predictions as elaborated in Table 2. Looking at standard deviation figures (above a thousand), Table 4 clearly shows that there are abnormal values in the GDP per capita, infrastructural development and exchange rate data. The probability figures (zero values) of the Jarque-Bera criteria is an indication that the data for all the variables used, except for human capital development, followed an abnormal distribution pattern. Given the need to deal with the twin problem of abnormal values and the abnormal distribution pattern, the author converted all the data sets into natural logarithms before further using it, in conformity with Abel and Le Roux (2016).

Panel unit root tests: In line with Taiwo and Olayemi (2015), the panel unit root tests for the current study include Fisher-tests using Philips-Perron (PP), Levin et al. (2002), Augmented Dickey-Fuller (ADF) and Im et al. (2003) - see Table 4. The tests followed an autoregressive-based general model (equation 4) as enunciated by Taiwo and Olayemi (2015, p. 78).

$$
g_{i t}=\mu_{i}+\Gamma_{i} t+\rho_{i} g_{i t-1}+\varepsilon_{i t}
$$

Where $\Gamma_{\mathrm{i}}$ stands for the individual trend, $t=1,2,3,4 \ldots . \mathrm{T}$, where $\mathrm{T}$ is the number of periods. $\mathrm{i}=1,2,3,4 \ldots \mathrm{N}$, where $\mathrm{N}$ is the number of countries. $\varepsilon_{i t}$ represents an error term. $\rho_{\mathrm{i}}$ is the autoregressive coefficient wherein if $\mathrm{I} \rho_{\mathrm{i}} \mathrm{I}<1, \mathrm{~g}_{\mathrm{it}}$ is weakly stationary, and if $\mathrm{I} \rho_{\mathrm{i}} \mathrm{I}=1, \mathrm{~g}_{\mathrm{it}}$ has a unit root.

Although some of the variables are stationary at level in Table 4, it is at the first difference stage where all the variables under study were found to be stationary. In other words, the data for the variables under study is integrated of order 1, a pre-condition for long-run relationship tests to be performed (Jiang and Liu 2014, p. 1208).

Panel co-integration tests: The study performed a co-integration test using the Kao Residual co-integration approach, whose finding (see Table 6) showed that the variables under study have a long-run relationship.

Table 6. Kao Residual Co-integration Test - Individual intercept

\begin{tabular}{|l|c|c|}
\hline & T-statistic & Probability \\
\hline Augmented Dickey-Fuller (ADF) & -3.1788 & 0.0000 \\
\hline
\end{tabular}

Source: Author's own compilation from E-Views. 


\section{Findings and analysis}

Table 7. Panel regression results for economic growth - Dynamic GMM results

\begin{tabular}{|l|c|c|c|c|}
\cline { 2 - 5 } \multicolumn{1}{l|}{} & Co-efficient & Std. error & t-statistic & Probability \\
\hline GDP Lag & $0.9261^{* * *}$ & 0.0220 & 42.0681 & 0.0000 \\
\hline INFR & 0.0560 & 0.0370 & 1.5133 & 0.1317 \\
\hline HCD & 0.4449 & 0.5504 & 0.8082 & 0.4198 \\
\hline INFR.HCD & $0.1391^{*}$ & 0.0764 & 1.8201 & 0.0814 \\
\hline FDI & $0.0288^{* *}$ & 0.0112 & 2.5597 & 0.0112 \\
\hline INFL & 0.0041 & 0.0117 & 0.3524 & 0.7249 \\
\hline SAV & 0.0425 & 0.0377 & 1.1278 & 0.2607 \\
\hline OPEN & -0.0241 & 0.0154 & -1.5719 & 0.1175 \\
\hline EXCH & 0.0053 & 0.0039 & 1.3586 & 0.1757 \\
\hline POP & 0.0073 & 0.0145 & 0.5075 & 0.6123 \\
\hline FIN & -0.0033 & 0.0058 & -0.5657 & 0.5722 \\
\hline
\end{tabular}

*** $/ * * / *$ indicate $1 \%, 5 \%$ and $10 \%$ significance levels respectively

Source: Author's own compilation from E-Views (8).

Using the dynamic GMM approach, the lag of GDP per capita had a significant positive impact on economic growth, in line with Levine et al. (2000) argument. The study also observed that infrastructural development positively but insignificantly influenced economic growth, in line with the literature (see sections 2 and 3). On the other hand, human capital development was found to have had a positive but insignificant influence on the growth of transitional economies. The finding resonates with arguments by Pradhan and Abraham (2002), whose study noted that human capital impacts growth through externalities effects and spillovers when educated and highly skilled workforce enter the labour market, thus bringing new ideas, technological innovations and technical expertise. The interaction between infrastructure and human capital development positively and significantly affected economic growth in transitional economies. This means that human capital development enhanced infrastructural development's ability to enhance economic growth in transitional countries, consistent with Kusharjanto and Kim (2011), whose study stated that electricity has the strongest impact on the human development index and, consequently, economic growth as it is widely used in almost all human activities, including education, health, transportation, households and technology.

In support of Sahoo's (2006) finding, the current study observed that economic growth in transitional countries was positive and significantly affected by the net inflow of FDI. Inflation, savings, exchange rates and population growth variables were separately found to have had a positive but insignificant influence on economic growth in transitional economies. These findings are supported by theoretical underpinnings elaborated in Table 2.

For robustness tests, equation 3 was then estimated using fixed effects, random effects and pooled OLS methods, the results of which are shown in Table 8. 
Table 8. Panel regression results for economic growth

\begin{tabular}{|l|c|c|c|c|c|c|}
\hline & \multicolumn{2}{|c|}{ Fixed effects } & \multicolumn{2}{c|}{ Random effects } & \multicolumn{2}{c|}{ Pooled OLS } \\
\cline { 2 - 7 } & Co-efficicent & t-statistic & Co-efficicent & t-statistic & Co-efficicent & t-statistic \\
\hline INFR & $2.14^{* * *}$ & 21.2930 & $1.58^{* * *}$ & 22.0526 & $1.20^{* * *}$ & 15.6909 \\
\hline HCD & -1.59 & -1.0269 & 1.6 & 1.1884 & 0.27 & 0.1634 \\
\hline $\begin{array}{l}\text { INFR. } \\
\text { HCD }\end{array}$ & 0.16 & 0.7589 & $-0.34^{*}$ & -1.8306 & -0.01 & -0.0361 \\
\hline FDI & $0.07^{* * *}$ & 3.2397 & $0.12^{* * *}$ & 6.0785 & $0.26^{* * *}$ & 8.6682 \\
\hline INFL & -0.03 & -1.3154 & 0.006 & 0.3038 & 0.05 & 1.3663 \\
\hline SAV & 0.20 & 1.6253 & -0.14 & -1.4867 & $-0.72^{* * *}$ & -7.1560 \\
\hline OPEN & $-0.38^{* * *}$ & -4.2232 & $-0.28^{* * *}$ & -5.0306 & -0.002 & -0.0470 \\
\hline EXCH & $-0.21^{* * *}$ & -3.1638 & $0.05^{* * *}$ & 2.8511 & $0.05^{* * *}$ & 4.7058 \\
\hline POP & 0.04 & 1.5149 & 0.03 & 1.2039 & $0.14^{* * *}$ & 3.2583 \\
\hline FIN & -0.002 & -0.1321 & -0.003 & -0.2400 & 0.003 & 0.1684 \\
\hline $\begin{array}{l}\text { R-squared 0.9787 } \\
\text { Adjusted R-squared 0.9762 }\end{array}$ & $\begin{array}{l}\text { R-squared 0.7958 } \\
\text { Adjusted R-squared 0.79 } \\
\text { F-statistic 383.78 } \\
\text { Prob (F-statistic) } 0.0000\end{array}$ & $\begin{array}{l}\text { R-squared 0.8965 } \\
\text { Adjusted R-squared } 0.89 \\
\text { Prob (F-statistic) } 0.0000\end{array}$ & $\begin{array}{l}\text { F-statistic 185.29 } \\
\text { Prob (F-statistic) } 0.0000\end{array}$ \\
\hline
\end{tabular}

*** $/ * * / *$ indicate $1 \%, 5 \%$ and $10 \%$ significance levels respectively

Source: Author's own compilation from E-Views (8).

Under fixed effects, infrastructural development had a significant positive impact on economic growth in transitional economies. By contrast, human capital development non-significantly influenced economic growth in a negative way. The reasoning is that increased expenditure to boost human capital development may have a negative influence on economic growth, especially when the skills acquired are not relevant to enhancing the economic growth trajectory of the country. On the other hand, the interaction between infrastructural development and human capital development had an insignificant positive influence on economic growth in transitional countries. The finding implies that human capital development is not a channel through which infrastructural development enhances economic growth in the transitional countries studied.

Under the random effects approach, whilst infrastructural development had a significant positive influence on economic growth, human capital development was found to have had an insignificant positive impact on economic growth in transitional economies. Contrary to theoretical predictions, the interaction between infrastructure and human capital development had a significant negative effect on the growth of the economy. The possible explanation could be that other factors apart from infrastructural and human capital development need to be in place for positive economic growth to happen in the transitional economies. These may include low corruption index, good governance, stable political atmosphere, among others which have not been taken into account in the current study. Findings concerning the separate impact of infrastructural and human capital development on economic growth under the pooled OLS approach are similar to the ones under the random effects model. The only notable dif- 
ference is that the interaction between infrastructural and human capital development had an insignificant negative influence on the growth of transitional economies.

Just like in the dynamic GMM model, FDI was found to have positively and significantly affected economic growth. Inflation negatively influenced economic growth under fixed effects whilst economic growth was positively impacted by inflation under both the random effects and the pooled OLS approaches. Savings had a positive influence on economic growth under the fixed effects approach, economic growth was negatively affected by savings under the random effects model whilst savings had a significant negative impact on economic growth under pooled OLS in transitional economies. Under both fixed and random effects, trade openness had a significant negative influence on economic growth whereas under pooled OLS, economic growth was negatively but non-significantly affected by trade openness. These findings are theoretically and empirically backed (see Table 2).

Whereas exchange rates had a significant negative impact on economic growth under the fixed effects, the random effects and pooled OLS approaches show that exchange rates significantly positively affected economic growth. Population growth had a non-significant positive impact on economic growth under both fixed and random effects approaches. On the other hand, population growth had a significant positive impact on economic growth under the pooled OLS framework. Although the pooled OLS approach shows that financial development had a positive non-significant influence on economic growth, both fixed and random effects observed that financial development negatively and insignificantly affected economic growth in transitional economies. The findings are in line with the theoretical predictions as illustrated in Table 2.

\section{Conclusion and recommendations}

This study investigated the impact of infrastructure and human capital development on economic growth in transitional economies. It also explored whether the interaction between infrastructural and human capital development enhanced economic growth in transitional economies. Although the literature is awash with studies which investigated the separate impact of infrastructure and human capital development on economic growth, no study that the author is aware of has so far explored whether the interaction between infrastructure and human capital development enhances economic growth. The study mainly used a dynamic panel GMM approach, a framework that takes into account the dynamic nature of economic growth data and addresses the endogeneity issues normally associated with economic growth regression functions. Panel data analysis approaches such as pooled OLS and fixed and random effects were used for comparison purposes and robustness tests. According to the dynamic GMM framework, the interaction between infrastructure and human capital development improved economic growth in transitional economies, in line with theoretical and empirical predictions. Random effects and pooled OLS show that the interaction between 
infrastructural and human capital development had a deleterious effect on economic growth whilst according to the fixed effects approach, the interaction between these two variables had an insignificant positive influence on economic growth in transitional economies. Considering that the results from a dynamic panel GMM are considered to be more accurate due to the approach's ability to address the endogeneity problem and the dynamic nature of economic growth data, the current study recommends that transitional economies should implement policies that improve human capital development in order to enhance infrastructural development's ability to influence economic growth. Future studies should investigate not just one (human capital development), but all the conditional factors which must be in place before economic growth advantages triggered by infrastructure development are realised.

\section{References}

Abel, S. and Le Roux, P. (2016), Determinants of banking sector profitability in Zimbabwe, 'International Journal of Economics and Financial Issues', 6 (3), pp. 845-854. Adu, G., Marbuah, G. and Mensah, J.T. (2013), Financial development and economic growth in Ghana: does the measure of financial development matter?, 'Review of Development Finance', 3, pp. 192-203.

Ajakaiye, O. and Ncube, M. (2010), Infrastructure and economic development in Africa: an overview, 'Journal of African Economics', 19 (1), pp. 3-12.

Anochiwa, L.I. and Maduka, A. (2014), Human capital, infrastructure and economic growth in Nigeria: an empirical evidence, 'Journal of Electrical and Electronics Engineering', 9 (4), pp. 1-6.

Arellano, M. and Bond, S. (1995), Another look at the instrumental variable estimators of error-component models, 'Journal of Econometrics', 68 (1), pp. 29-52.

Banerjee, A., Duflo, E. and Qian, N. (2012), On the road: access to transportation infrastructure and economic growth in China, National Bureau of Economic Research, Working paper No. 17897.

Batuo, M.E. (2015), The role of telecommunications infrastructure in the regional economic growth of Africa, 'The Journal of Developing Areas', 49 (1), pp. 313-330.

Buys, P., Deichmann, U. and Wheeler, D. (2010), Road network upgrading and overland trade expansion in Su-Saharan Africa, 'Journal of African Economics', 19 (3), pp. 399-432.

Calderon, C. and Serven, L. (2010), Infrastructure and economic development in Sub-Saharan Africa, 'Journal of African Economics', 19 (1), pp. 13-87.

Cantu, C. (2017), Mexico's economic infrastructure: international benchmark and its impact on growth, 'Journal of Economic Structures', 6 (33), pp. 1-26.

Cavusgil, S.T., Ghauri, P.N. and Akcal, A.A. (2013), Doing business in emerging markets. Sage Publications, $2^{\text {nd }}$ Edition.

Chang, R., Kaltani, L. and Loayza, N.V. (2009), Openness can be good for growth: the role of policy complementaries, 'Journal of Development Economics', 90 (1), pp. 33-49. 
Chirwa, T.G. and Odhiambo, N.M. (2016), The drivers of real sector growth in Malawi: an empirical investigation, UNISA Economic Research, working paper No. 3.

Crescenzi, R. and Rodriguez-Pose, P. (2012), Infrastructure and regional growth in the European Union, Papers in Regional Science, 91 (3), pp. 487-615.

Daido, K. and Tabata, K. (2013), Public infrastructure, production organization, and economic development, 'Journal of Macroeconomics', 38, pp. 330-346.

Donou-Adonsou, F. and Lim, S. (2016), Technological progress and economic growth in Sub-Saharan Africa: evidence from telecommunications infrastructure, 'International Advancement of Economic Research', 22, pp. 65-75.

Farhadi, M. (2015), Transport infrastructure and long-run economic growth in OECD countries, 'Transportation Research Part A', 74 (April), pp. 73-90.

Frone, S. and Fone, D.F. (2014), Challenges in analyzing correlation between water infrastructure and economic development, 'Procedia Economics and Finance', 10, pp. 197-206.

Gui-Diby, S.L. (2014), Impact of foreign direct investments on economic growth in Africa: evidence from three decades of panel data analyses, 'Research in Economics', 68 , pp. 248-256.

Huchet-Bourdon, M., Mouel, C.L. and Vijil, M. (2018), The relationship between trade openness and economic growth: some new insights on the openness measurement issue, 'The World Economy', 41, pp. 59-76.

Im, K.S., Pesaran, M.H. and Shin, Y. (2003), Testing unit roots in heterogeneous panels, 'Journal of Econometrics', 115 (1), pp. 53-74.

International Monetary Fund. 2015, World Economic Outlook: Adjusting to Lower Commodity Prices, Washington (October).

Jagadeesh, D. (2015), The impact of savings in economic growth: an empirical study based on Botswana, 'International Journal of Research in Business Studies and Management', 2 (9), pp. 10-21.

Jiang, H. and Liu, C. (2014), A panel vector error correction approach to forecasting demand in regional construction markets, 'Construction Management and Economics', 32 (12), pp. 1205-1221.

Jiang, X., He, X., Zhang, L., Qin, H. and Shao, F. (2017), Multimodal transportation infrastructure investment and regional economic development: a structural equation modelling empirical analysis in China from 1986 to 2011, 'Transport Policy', 54 (February), pp. 43-52.

Jorgenson, D.W. (1963), Capital theory and investment behavior, 'The American Economic Review', 53 (2), pp. 247-259.

Keynes, J.M. (1936), The general theory of employment, interest and money, New York: Harcourt, Brace and Co.

Kodongo, O. and Ojah, K. (2016), Does infrastructure really explain economic growth in Sub-Saharan Africa?, 'Review of Development Finance', 6 (December), pp. 105125.

Korkmaz, S. (2013), The effect of exchange rate on economic growth, Conference paper Oct 2013. 
Kumari, A. and Sharma, A.K. (2017), Physical \& social infrastructure in India \& its relationship with economic development, 'World Development Perspectives', 5 (March), pp. 30-33.

Kusharjanto, H. and Kim, D. (2011), Infrastructure and human development: the case of Java, 'Indonesia, Journal of the Asia Pacific Economy', 16 (1), pp. 111-124.

Levine, R., Loayza, N. and Beck, T. (2000), Financial intermediation and growth: Causality and causes, 'Journal of Monetary Economics', 46 (1), pp. 31-77.

Levin, A., Lin, C.F. and Chu, C.S.J. (2002), Unit root tests in panel data: Asymptotic and finite-sample properties, 'Journal of Econometrics', 108 (1), pp. 1-24.

Mahembe, E. and Odhiambo, N.M. (2014), Foreign direct investment and economic growth: a theoretical framework, 'Journal of Governance and Regulation', 3 (2), pp. 63-70.

Matalqah, M.M. and Warad, T.M. (2017), The impact of telecom infrastructure on the economic growth: the case of oil-producing and non-oil producing Arab countries, 'International Journal of Economics and Financial Issues', 7 (3), pp. 423-428.

Meersman, H. and Nazemzadeh, M. (2017), The contribution of transport infrastructure to economic activity: the case of Belgium, 'Case studies on Transport Policy', 5 (2), pp. 316-324.

Miftahu, I. and Rosni, B. (2017), The relationship between inflation and economic growth in Nigeria: a conceptual approach, 'Asian Research Journal of Arts \& Social Sciences', 3 (1), pp. 1-15.

Pietak, L. (2014), Review of theories and models of economic growth, 'Comparative Economic Research', 17 (1), pp. 46-60.

Pradhan, J.P. and Abraham, V. (2002), Does human development policy matter for economic growth? Evidence from Indian states, 'South Asia Economic Journal', 3 (1), pp. 78-93.

Pradhan, R.P. and Bagchi, T.P. (2012), Effect of transportation infrastructure on economic growth in India: the VECM approach, 'Research in Transportation Economics', 38 (1), pp. 139-148.

Pradhan, R.P., Arvin, M.B., Norman, N.R. and Bele, S.K. (2014), Economic growth and the development of telecommunications infrastructure in the G-20 countries: a panel-VAR approach, 'Telecommunications Policy'. 38, pp. 634-649.

Prud'homme, R. (2004), Infrastructure and development, Annual Bank Conference on Development Economics, Washington DC.

Redding, S.J and Turner, M.A. (2014), Transportation costs and the spatial organisation of economic activity, National Bureau of Economic Research, Working paper No. 20235.

Rodriguez-Pose, A. Psycharies, Y. and Tselios, V. (2012), Public investment and regional growth and convergence: evidence from Greece, 'Papers in Regional Science', 91 (3), pp. 543-568.

Sahin, O., Can, N. and Demirbas, E. (2014), The effects of infrastructure determinants on economic growth: European Union sample, 'Eurasian Journal of Business and Economics', 7 (13), pp. 11-27.

Sahoo, P. (2006), Foreign direct investment in South Asia: policy, trends, impact and determinants, ABD Institute, Discussion Paper No. 56. 
Sahoo, P. and Dash, R.J. (2012), Economic growth in South Asia: role of infrastructure, 'The Journal of International Trade \& Economic Development', 21 (2), pp. 217-252. Sahoo, P., Dash, R.K. and Nataraj, G. (2012), China's growth story: the role of physical and social infrastructure, 'Journal of Economic Development', 37 (1), pp. 53-75.

Shabani, Z.D. and Safaie, S. (2018), Do transport infrastructure spillovers matter for economic growth? Evidence on road and railway transport infrastructure in Iranian provinces, 'Regional Science Policy and Practice', 10, pp. 49-63.

Shafiq, M.N. (2007), Household schooling and child labour decisions in rural Bangladesh, 'Journal of Asian Economics', 18, pp. 946-966.

Shi, Y., Guo, S. and Sun, P. (2017), The role of infrastructure in China's regional economic growth, 'Journal of Asian Economics', 49 (April), pp. 26-41.

Stead, R. (1996), Foundation quantitative methods for business, Prentice Hall. England.

Straub, S. (2007), Infrastructure: recent advances and research challenges (unpublished manuscript).

Taiwo, A. and Olayemi, S.O. (2015), Re-examine foreign direct investment and economic growth: Panel co-integration and causality tests for sub-Saharan African countries, 'International Area Studies Review', 18 (1), pp. 73-86.

Turan, G. and Gjergji, O. (2014), What is the impact of savings on growth? The case of a small open economy (Albania), 'Mediterranean Journal of Social Sciences', 5 (13), pp. 360-368.

Wooldridge, J.M. (2002), Econometric analysis of cross section and panel data, Cambridge MA: MIT Press.

Wu, J., Deng, Y., Huang, J., Morck, R. and Yeung, B. (2013), Incentives and outcomes: China's environmental policy, National Bureau of Economic Research, Working paper No. 18754.

Zahonogo, P. (2016), Trade and economic growth in developing countries: evidence from sub-Saharan Africa, 'Journal of African Trade', 3, pp. 41-56.

Zheng, D. and Kuroda, T. (2013), The role of public infrastructure in China's regional inequality and growth: a simultaneous equations approach, 'The Developing Economies', 1 (March 2013), pp. 79-109.

\section{Streszczenie}

\section{Infrastruktura, rozwój kapitału ludzkiego i wzrost gospodarczy w krajach przejściowych}

W niniejszym opracowaniu poddano analizie wpływ rozwoju infrastruktury i kapitału ludzkiego na wzrost gospodarczy w gospodarkach przechodzących proces transformacji. Zbadano również, czy interakcje między rozwojem infrastruktury a rozwojem kapitału ludzkiego przyczyniły się do wzrostu gospodarczego w tych gospodarkach. Mimo że literatura przedmiotu obejmuje wiele opracowań, poświęconych zbadaniu odrębnego wpływu rozwoju infrastruktury i rozwoju kapitału ludzkiego na wzrost gospodarczy, to jednak żadne ze znanych autorowi badań nie było poświęcone próbie 
udzielenia odpowiedzi na pytanie, czy interakcje między infrastrukturą a rozwojem kapitału ludzkiego sprzyjają wzrostowi gospodarczemu. W badaniu wykorzystano głównie uogólnione metody momentów (dynamic panel GMM) autorstwa Arellano i Bonda (1995), które uwzględniają dynamiczny charakter danych dotyczących wzrostu gospodarczego i rozwiązują problemy endogeniczności normalnie związane z funkcjami regresji wzrostu gospodarczego. Metody analizy danych panelowych, takie jak metoda najmniejszych kwadratów (pooled OLS) oraz metody z efektami stałymi i losowymi zostały użyte do celów porównawczych i przeprowadzenia testów odporności. Zgodnie z dynamicznym podejściem opartym na uogólnionych metodach momentów (GMM), interakcje między rozwojem infrastruktury a rozwojem kapitału ludzkiego przyczyniły się do zwiększenia wzrostu gospodarczego w gospodarkach przechodzących transformację, zgodnie z przewidywaniami teoretycznymi i empirycznymi. Metoda z efektami losowymi i metoda najmniejszych kwadratów (pooled OLS) pokazują, że interakcje między rozwojem infrastruktury a rozwojem kapitału ludzkiego miały szkodliwy wpływ na wzrost gospodarczy, natomiast zgodnie z metodą z efektami stałymi interakcje między tymi dwiema zmiennymi miały niewielki pozytywny wpływ na wzrost gospodarczy w gospodarkach przechodzących transformację. Biorąc pod uwagę, że wyniki otrzymane metodą uogólnionych momentów (GMM) są uważane za dokładniejsze ze względu na możliwość uwzględnienia problemu endogeniczności i dynamiczny charakter danych dotyczących wzrostu gospodarczego, z niniejszego badania wynika zalecenie, aby gospodarki przechodzące transformację wdrożyły polityki, które wspierają rozwój kapitału ludzkiego w celu zwiększenia zdolności rozwoju infrastruktury do wpływania na wzrost gospodarczy. Przyszłe badania powinny obejmować nie tylko jeden (rozwój kapitału ludzkiego), ale wszystkie warunki, które muszą być spełnione aby rozwój infrastruktury mógł przyczynić się do osiągnięcia korzyści ekonomicznych.

Słowa kluczowe: kapitał ludzki; infrastruktura; gospodarki przechodzące transformację; metoda uogólnionych momentów (dynamic GMM) 